\title{
Peritoneal Pain
}

National Cancer Institute

\section{Source}

National Cancer Institute. Peritoneal Pain. NCI Thesaurus. Code C78546.

Painful sensation in the peritoneum. 